\title{
Coal Mines in Vietnam: Geological Conditions and Their Influence on Production Sustainability Indicators
}

\author{
Chu Thi Que (D, Marina Nevskaya * and Oksana Marinina \\ Department of Organization and Management, Saint-Petersburg Mining University, \\ 199106 Saint-Petersburg, Russia; chuthique.ncs@gmail.com (C.T.Q.); Marinina_OA@pers.spmi.ru (O.M.) \\ * Correspondence: ma.nevsk@yandex.ru; Tel.: +7-921-358-3380
}

check for

updates

Citation: Que, C.T.; Nevskaya, M.; Marinina, O. Coal Mines in Vietnam: Geological Conditions and Their

Influence on Production

Sustainability Indicators.

Sustainability 2021, 13, 11800.

https://doi.org/10.3390/su132111800

Academic Editors:

Izabela Jonek-Kowalska and

Lilla Knop

Received: 18 September 2021

Accepted: 22 October 2021

Published: 26 October 2021

Publisher's Note: MDPI stays neutral with regard to jurisdictional claims in published maps and institutional affiliations.

Copyright: (c) 2021 by the authors. Licensee MDPI, Basel, Switzerland. This article is an open access article distributed under the terms and conditions of the Creative Commons Attribution (CC BY) license (https:/ / creativecommons.org/licenses/by/ $4.0 /)$.

\begin{abstract}
The high growth rate that the Vietnamese economy has been demonstrating in recent years largely depends on the use of the country's fossil fuel reserves, which form the foundation of its fuel and energy sector. The country will have to rely on coal as one of the key energy sources for a long time in order to meet its energy needs. Since coal has been mined in Vietnam for a long time, the country is now facing such challenges as the depletion of readily available reserves and an increase in the share of coal mined underground in difficult geological conditions. These circumstances may affect the sustainability of the coal industry as a whole. The purpose of the study is to develop a method for analyzing the influence of geological conditions on production sustainability indicators at coal mines operated by Vinacomin, a state-owned corporation. Research methods include substantiating and choosing objects and indicators reflecting production sustainability at coal mines, formalizing the qualitative characteristics of geological conditions, and revealing the relationship between the complexity of geological conditions and production sustainability indicators. As a result of the analysis, the most problematic mines and their operations were identified. They should be given priority attention when developing measures and corporate programs aimed at fostering the sustainability of coal mines. The results of the study provide new knowledge on the coal industry in Vietnam and help to develop methods for assessing corporate sustainability.
\end{abstract}

Keywords: coal mines; production sustainability; geological conditions; coal mine sustainability assessment methods; sustainability indicators

\section{Introduction}

The Socialist Republic of Vietnam (SRV) is a country with a rapidly growing economy. According to [1], the rate of economic growth in 2019 reached 6.5\%. In terms of growth rates, the Vietnamese economy outperforms those of other Asia-Pacific countries (China, Indonesia, and Malaysia). The high growth rate is explained by industrial growth witnessed primarily in the energy sector, which supports all sectors of the national economy. Coalfired power plants generate almost a third of the country's energy (28\%) [2].

Developing countries in the Asia-Pacific region heavily rely on coal to meet their demand for energy. Coal mines cause significant water and soil pollution, which creates problems in interaction between coal companies and the local population [3].

For some European countries, coal also continues to be an important energy source [4], although the adoption of the Paris Agreement became an impetus for the EU countries to reduce their consumption of fossil fuels [5].

Coal production and consumption consequences manifest themselves in land degradation, environmental pollution caused by mine water [6], and soil pollution cause by coal combustion waste (ash) [7]. Methane emissions from coal mining contribute to climate change [8].

The desire of the global community to reduce greenhouse gas emissions by curbing the production and consumption of carbon-based fuels (primarily coal) that is reflected in the 
Sustainable Development Goals (SDGs) has also made an impact on Vietnam's economic policy. With regard to energy sources, this policy provides for ensuring the country's energy security through fostering the development of the renewable energy sector, saving energy, and rationalizing coal exports and imports $[9,10]$.

Nevertheless, the needs of the developing economy for electricity will not allow Vietnam to abandon fossil fuels either in the long or short term [11]. According to the Program for the Development of the Coal Industry of the Socialist Republic of Vietnam until 2035, the demand for coal in 2030 is expected to be 2.5 times bigger than in 2019, when it amounted to 43.35 million tons, and almost 3 times bigger in 2035 [12,13]. This shows that the role of coal and the coal industry in the development of the Vietnamese economy is still very important. According to [1], the country's coal reserves will last for 75 years at the current output figures. However, since 2015, the coal industry has not been fully meeting the growing energy needs, and it is expected that this gap will only grow $[14,15]$, which will require bigger coal imports. For more than a century, the country's coal reserves with favorable geological conditions have been mined in open pits, and now they are being depleted.

Underground mining currently accounts for $65 \%$ of Vietnamese coal output, and it is planned to raise this share up to $90 \%$ by $2030[12,15]$. Difficult geological conditions (the tectonic features and the bedding parameters of coal seams in Vietnam make them uniquely difficult to mine) create obstacles for the development of the coal industry. The key issues are associated with the use of outdated technologies, difficult working conditions, and a high level of industrial hazards (rock bursts, methane outbursts, etc.) [16-18].

What makes the country's coal industry special is that it is highly concentrated: more than $80 \%$ of coal output is produced by Vinacomin, a large state-owned corporation, which operates twenty facilities (fourteen underground mines and six open-pit mines) [11].

Global trends and other factors influencing the functioning of the coal industry were the reasons for adjusting the government program for its development: the original plan to significantly increase coal production was abandoned and replaced with a plan that aims to stabilize coal production growth (in 2030, the growth rate is expected to be slightly over $1 \%$ compared to 2020) and places emphasis on meeting the needs of the country's thermal power stations firsthand.

Studies [19] note that business operations in the energy industry are complicated by the complexity and capital intensity of the resources and processes used. In the current market environment, an additional challenge is the trend towards sustainable development, which includes setting and achieving environmental and social goals. These circumstances require effective and efficient management that takes into account location specifics, geological conditions, and technological requirements associated with the development of coal deposits.

Assessing the sustainable development of mining companies in the context of the global sustainable development concept serves as a foundation for developing management decisions regarding how to make sure that various social, economic, and environmental activities of both individual businesses and the economy as a whole are effective [20,21].

It is of importance for the economy of Vietnam to maintain stable coal production while ensuring a certain level of economic efficiency and safe working conditions at the country's operating facilities, primarily at coal mines. Therefore, in this study, sustainability is considered as the ability of any production system to maintain the stability of its parameters under the influence of the external environment [22].

Geological conditions are a complex external factor affecting coal production as well as the social and environmental performance of coal mines and should be taken into account when choosing priority areas in developing plans for the sustainable functioning of the industry. The lack of methods for quantifying this factor determines the need for its development.

In the course of the study, several kinds of analysis were used to improve methods for assessing corporate sustainability: 
- quantitative assessment of the complexity of the geological conditions at the coal mines operated by Vinacomin;

- calculating indicators of production sustainability based on a case study of Vinacomin mines;

- correlation and regression analysis of the relationship between production sustainability indicators and the complexity of geological conditions.

The steps of the study made it possible to test the hypothesis about the influence of geological conditions on the productivity of coal mines, and, consequently, on their sustainability. It also made it possible to answer the key research question (RQ), namely that of the relationship between the indicator of geological conditions and the indicators of production sustainability that include annual coal production volume, coal quality, workforce productivity, the fatal injury rate, and the volume of contaminated mine water discharge.

\section{Materials and Methods}

The research algorithm includes the following: a rationale for choosing the object of study; substantiating criteria and selecting indicators that characterize coal mines from the viewpoint of their production sustainability; checking for correlations between indicators; a quantitative assessment of the parameters that determine the complexity of geological conditions at each mine; ranking mines by the complexity of their geological conditions; identifying the relationship between production sustainability indicators and the complexity of geological conditions.

\subsection{Choosing the Object of Study}

As objects of study, thirteen underground coal mines were chosen that are part of the mining division of the Vinacomin corporation. As noted earlier, the company's share in the total coal output of the country exceeds $85 \%$. In $2019,65 \%$ of this share was accounted for by underground mining, i.e., more than $55 \%$ of Vietnamese coal production comes from underground mines operated by the Vinacomin company, and it is expected that this share will grow, reaching $76.5 \%$ by 2030 [11]. This is what makes them important objects for the economy of Vietnam.

The coal mines discussed produce coal from the Quang Ninh coalfield. As the main mining method, drilling and blasting prevail, with broken coal being loaded manually onto conveyor belts. The mines are independent only in their production operations. All commercial and financial activities are controlled by Vinacomin. The key sources supporting the mines are government loans and depreciation deductions, which are used to maintain production and cannot be considered as a means of development.

\subsection{Production Sustainability Criteria and Indicators}

Stability, safety, and efficiency were chosen as the key sustainability criteria.

The stability criterion corresponds to the long-term objectives regarding the development of the coal industry in Vietnam as a planned economy that needs to maintain a certain level of coal production and quality. Therefore, to analyze stability, production volumes and the integrated coal quality index were chosen [23].

In terms of safety, we focus on environmental and occupational aspects. The volume of mine water discharge was chosen as an indicator characterizing environmental sustainability. To assess occupational safety, the fatal injury rate was chosen as the key indicator.

Efficiency means how well coal mines use their resources. As the information on costs is confidential, workforce productivity was chosen as the key indicator since it greatly affects the cost price.

The quantitative values of the indicators were calculated based on the reports published by the company for years 2018 to 2020. Production volumes and mine water discharge were calculated in absolute terms as average annual values.

Workforce productivity was calculated as the ratio between the average annual coal production to the average annual number of workers.

The fatal injury rate was calculated per 1 million tons of coal produced. 
The values of the integrated coal quality index were calculated using the method described in [23], which factors in such parameters as ash, sulfur, and water contents as well as the calorific value of coal.

\subsection{Quantitative Assessment of the Complexity of Geological Conditions}

Quantitative assessment of the complexity of geological conditions was performed based on the following geological parameters: seam thickness variability, qualitative characteristics, enclosing rock thickness, hydrogeological conditions (water inflow), and methane content [24].

The mines were ranked by each criterion on a scale ranging from 1 to 4 . The lowest score represents easy geological conditions, and the highest score represents very difficult geological conditions. The scores were then summed up, creating a ranking of the mines by the complexity of their geological conditions. The qualitative characteristics of the coal seams at each mine were assessed by the company's geologists with the help of a simplified algorithm: based on the total combination of characteristics, the geological conditions of each site were classified as easy, moderately difficult, difficult, or very difficult.

To assess the weight of each criterion determining the complexity of geological conditions, a survey was conducted among the company's employees (26 people), who were asked to assign a weight to each criterion on a 10-point scale. The higher the weight, the more important this criterion is in the assessment.

To evaluate the relationship between geological conditions and sustainability, regression analysis was performed using Chaddock's scale to assess the strength of relationship.

\subsection{Materials}

Since desk research is the key method used in the study, we relied on official reports issued by the Vinacomin corporation and also on publicly available research data and information on the topic.

\section{Results}

Table 1 shows the production sustainability indicators that were used for further analysis.

Table 1. Production sustainability indicators at coal mines.

\begin{tabular}{|c|c|c|c|c|c|}
\hline \multirow{2}{*}{ Coal Mine } & \multicolumn{2}{|c|}{ Production } & \multirow{2}{*}{$\frac{\text { Economic }}{\mathbf{P}}$} & \multirow{2}{*}{$\begin{array}{c}\text { Social } \\
\text { Ac }\end{array}$} & \multirow{2}{*}{$\frac{\text { Environmental }}{\mathrm{Wd}}$} \\
\hline & $\mathbf{V}$ & Jc & & & \\
\hline Vang Danh & 2873 & 2.19 & 762.0 & 0.26 & 1729.17 \\
\hline Mao Khe & 1690 & 1.23 & 604.6 & 1.48 & 6323.83 \\
\hline Trang Bach & 2669 & 1.68 & 1004.8 & 0.56 & 4065.20 \\
\hline Nam Mau & 2026 & 1.79 & 632.9 & 0.74 & 1853.78 \\
\hline Ha Lam & 2361 & 1.40 & 1387.7 & 0.21 & 1703.31 \\
\hline Non Gai & 1710 & 1.32 & 794.1 & 1.17 & 3815.14 \\
\hline Mong Duong & 1442 & 1.64 & 671.1 & 1.04 & 3918.17 \\
\hline Khe Cham & 1654 & 2.02 & 620.4 & 0.76 & 2918.16 \\
\hline Khe Cham 3 & 1468 & 1.47 & 781.7 & 1.53 & 879.88 \\
\hline Khe Tam & 1919 & 1.34 & 838.1 & 0.39 & 5691.22 \\
\hline Nga Hai & 1480 & 1.40 & 645.9 & 1.01 & 785.00 \\
\hline Thong Nhat & 1812 & 2.34 & 800.6 & 0.83 & 1987.11 \\
\hline Nui Beo & 525 & 1.75 & 392.1 & 1.43 & 1890.71 \\
\hline
\end{tabular}

Sources: calculated by the authors based on [11,12,24-29].

In Table $1, \mathrm{~V}$ is the average annual production volume, $10^{6} \mathrm{~kg}$, Jc is the integrated coal quality index, $\mathrm{P}$ is the average annual workforce productivity, $10^{3} \mathrm{~kg} /$ person, Ac is the 
average annual number of fatal injuries at work, number $/ 10^{9} \mathrm{~kg}$, and $\mathrm{Wd}$ is the average annual mine water discharge, $10^{3} \mathrm{~m}^{3}$.

Criteria for assessing geological conditions are shown in Table 2.

Table 2. Criteria for ranking coal mines by the complexity of geological conditions.

\begin{tabular}{|c|c|c|c|c|}
\hline Criterion & Easy & Moderately Difficult & Difficult & Very Difficult \\
\hline Seam thickness variability, \% & $<40$ & $40-75$ & $75-100$ & $>100$ \\
\hline $\begin{array}{l}\text { Qualitative characteristics } \\
\text { (mode of occurrence, } \\
\text { deformation, structure) }\end{array}$ & $\begin{array}{l}\text { Flat-lying, very thick, } \\
\text { undeformed coal seams }\end{array}$ & $\begin{array}{l}\text { Dipping coal seams with } \\
\text { minor deformations that } \\
\text { are easy to identify }\end{array}$ & $\begin{array}{l}\text { Dipping coal seams with } \\
\text { multiple folds, secondary } \\
\text { folds, faults, and complex } \\
\text { secondary faulting }\end{array}$ & $\begin{array}{l}\text { Thin to very thin seams } \\
\text { and lenticular coal seams; } \\
\text { coal mines are located } \\
\text { with a distribution area of } \\
\text { less than } 2 \mathrm{~km}^{2}\end{array}$ \\
\hline Enclosing rock thickness, $\mathrm{m}$ & less than 20 & $20-50$ & $50-80$ & $>80$ \\
\hline $\begin{array}{l}\text { Hydrogeological conditions } \\
\text { (water inflow), } \mathrm{m}^{3} / \mathrm{h}\end{array}$ & not exceeding 100 to 200 & $200-500$ & $500-1.000$ & $1.000-2.000$ \\
\hline Methane content, $\mathrm{m}^{3} / 10^{3} \mathrm{~kg}$ & $<5$ & from 5 to 10 & from 10 to 15 & $>15$ \\
\hline
\end{tabular}

The information presented in Table 2 makes it possible to classify each mine in terms of the complexity of its geological conditions by each individual criterion.

Characteristics of the geological conditions at the coal mines operated by Vinacomin are presented in Table 3.

Table 3. Geological conditions at Vinacomin coal mines.

\begin{tabular}{|c|c|c|c|c|c|}
\hline \multirow[b]{2}{*}{ Coal Mine } & \multicolumn{5}{|c|}{ Characteristics } \\
\hline & $\begin{array}{c}\text { Seam Thickness } \\
\text { Variability, } \\
\%\end{array}$ & $\begin{array}{c}\text { Qualitative } \\
\text { Characteristics }\end{array}$ & $\begin{array}{c}\text { Enclosing Rock } \\
\text { Thickness, } \\
\text { m }\end{array}$ & $\begin{array}{c}\text { Hydrogeological } \\
\text { Conditions, } \\
\mathrm{m}^{3} / \mathrm{h}\end{array}$ & $\begin{array}{c}\text { Methane Content, } \\
\mathrm{m}^{3} / 10^{3} \mathrm{~kg}\end{array}$ \\
\hline Vang Danh & 26 & Easy & $\mathrm{No}$ & 223 & 2.88 \\
\hline Mao Khe & 121 & Very difficult & 76 & 591 & 20.07 \\
\hline Trang Bach & 74 & Easy & 17 & 506 & 5.81 \\
\hline Nam Mau & 97 & Difficult & 73 & 1082 & 1.31 \\
\hline Ha Lam & 32 & $\begin{array}{l}\text { Moderately } \\
\text { difficult }\end{array}$ & 14 & 214 & 0.95 \\
\hline Hon Gai & 68 & Very difficult & 84 & 225 & 1.45 \\
\hline Mong Duong & 114 & Very difficult & 91 & 1074 & 5.45 \\
\hline Khe Cham & 74 & Easy & No & 261 & 14.9 \\
\hline Khe Cham 3 & 101 & Difficult & 79 & 1997 & 5.81 \\
\hline Khe Tam & 19 & $\begin{array}{l}\text { Moderately } \\
\text { difficult }\end{array}$ & 36 & 111 & 5.04 \\
\hline Nga Hai & 76 & Difficult & 47 & 1057 & 11.37 \\
\hline Thong Nhat & 46 & Easy & No & 197 & 5.85 \\
\hline Nui Beo & 26 & Easy & $\mathrm{No}$ & 204 & 0.73 \\
\hline
\end{tabular}

Sources: compiled by the authors based on the data presented in Table 2 and using [26].

The results of the qualitative assessment of the coal mines based on the complexity of geological conditions are presented in Table 4 . 
Table 4. Quantitative assessment of the complexity of geological conditions at coal mines.

\begin{tabular}{|c|c|c|c|c|c|c|c|}
\hline \multirow[b]{2}{*}{ Coal Mine } & \multicolumn{5}{|c|}{ Parameter Scoring } & \multirow[b]{2}{*}{ Total } & \multirow{2}{*}{$\begin{array}{c}\text { Weighted } \\
\text { Total }\end{array}$} \\
\hline & $\begin{array}{c}\text { Seam Thickness } \\
\text { Variability }\end{array}$ & $\begin{array}{c}\text { Qualitative } \\
\text { Characteristics }\end{array}$ & $\begin{array}{l}\text { Enclosing Rock } \\
\text { Thickness }\end{array}$ & $\begin{array}{l}\text { Hydrogeological } \\
\text { Conditions }\end{array}$ & $\begin{array}{l}\text { Methane } \\
\text { Content }\end{array}$ & & \\
\hline Criterion weight & 0.204 & 0.207 & 0.172 & 0.204 & 0.213 & 1 & \\
\hline Vang Danh & 1 & 1 & 1 & 2 & 1 & 6 & 1.2 \\
\hline Mao Khe & 4 & 4 & 3 & 3 & 4 & 18 & 3.62 \\
\hline Trang Bach & 2 & 1 & 1 & 3 & 2 & 9 & 1.83 \\
\hline Nam Mau & 3 & 3 & 3 & 4 & 1 & 14 & 2.78 \\
\hline Ha Lam & 1 & 2 & 1 & 2 & 1 & 7 & 1.41 \\
\hline Hon Gai & 2 & 4 & 4 & 2 & 1 & 11 & 2.55 \\
\hline Mong Duong & 4 & 4 & 4 & 3 & 2 & 17 & 3.37 \\
\hline Khe Cham & 2 & 1 & 1 & 2 & 3 & 9 & 1.83 \\
\hline Khe Cham 3 & 4 & 3 & 3 & 4 & 2 & 16 & 3.2 \\
\hline Khe Tam & 1 & 2 & 2 & 1 & 2 & 8 & 1.59 \\
\hline Nga Hai & 3 & 3 & 2 & 4 & 3 & 15 & 3.03 \\
\hline Thong Nhat & 2 & 1 & 1 & 1 & 2 & 7 & 1.42 \\
\hline Nui Beo & 1 & 1 & 1 & 2 & 1 & 6 & 1.2 \\
\hline
\end{tabular}

Source: compiled by the authors.

The table shows score distribution depending on the complexity of geological conditions by the established criteria. Taking into account the weight of each criterion, the total score was calculated that reflects the degree of condition complexity.

Assessment of the influence of geological conditions on the sustainability of coal mines.

The results of ranking the coal mines by the complexity of geological conditions and the corresponding indicators of production sustainability are presented in Table 5.

Table 5. Coal mine ranking by the complexity of geological conditions.

\begin{tabular}{ccccccc}
\hline \multirow{2}{*}{ Coal Mine Ranking } & \multirow{2}{*}{ Geological Condition Score } & \multicolumn{3}{c}{ Production Sustainability Indicators } \\
\cline { 3 - 7 } & & V & Jc & P & Ac & Wd \\
\hline Vang Danh & 1.2 & 2873 & 2.19 & 762.0 & 0.26 & 1729.2 \\
\hline Nui Beo & 1.2 & 525 & 1.75 & 392.1 & 1.43 & 1890.7 \\
\hline Ha Lam & 1.41 & 2361 & 1.4 & 1387.7 & 0.21 & 1703.3 \\
\hline Thong Nhat & 1.42 & 1812 & 2.34 & 800.6 & 0.83 & 1987.1 \\
\hline Khe Tam & 1.59 & 1919 & 1.34 & 838.1 & 0.39 & 5691.2 \\
\hline Trang Bach & 1.83 & 2669 & 1.68 & 1005.8 & 0.56 & 4065.2 \\
\hline Khe Cham & 1.83 & 1654 & 2.02 & 620.4 & 0.76 & 2918.2 \\
\hline Hon Gai & 2.55 & 1710 & 1.32 & 794.1 & 1.17 & 3815.1 \\
\hline Nam Mau & 2.78 & 2026 & 1.79 & 632.9 & 0.74 \\
\hline Nga Hai & 3.03 & 1480 & 1.4 & 645.9 & 1.01 & 785.0 \\
\hline Khe Cham 3 & 3.2 & 1468 & 1.47 & 781.7 & 1.53 \\
\hline Mong Duong & 3.37 & 1442 & 1.64 & 671.1 & 1.04 \\
\hline Mao Khe & 3.62 & 1.690 & 1.23 & 604.6 & 1.48 & 6323.9 \\
\hline
\end{tabular}

Source: compiled by the authors.

In Table $5, \mathrm{~V}$ is the average annual production volume, $10^{6} \mathrm{~kg}$, Jc is the integrated coal quality index, $\mathrm{P}$ is the average annual workforce productivity, $10^{3} \mathrm{~kg} /$ person, Ac is the 
average annual number of fatal injuries at work, number $/ 10^{9} \mathrm{~kg}$, Wd is the average annual mine water discharge, $10^{3} \mathrm{~m}^{3}$.

This table presents a ranking of the mines that was used to identify whether there is a significant relationship between the complexity of geological conditions and the indicators of production sustainability.

Figures 1-5 present graphs illustrating the relationships between production sustainability indicators and the indicators for assessing geological conditions.

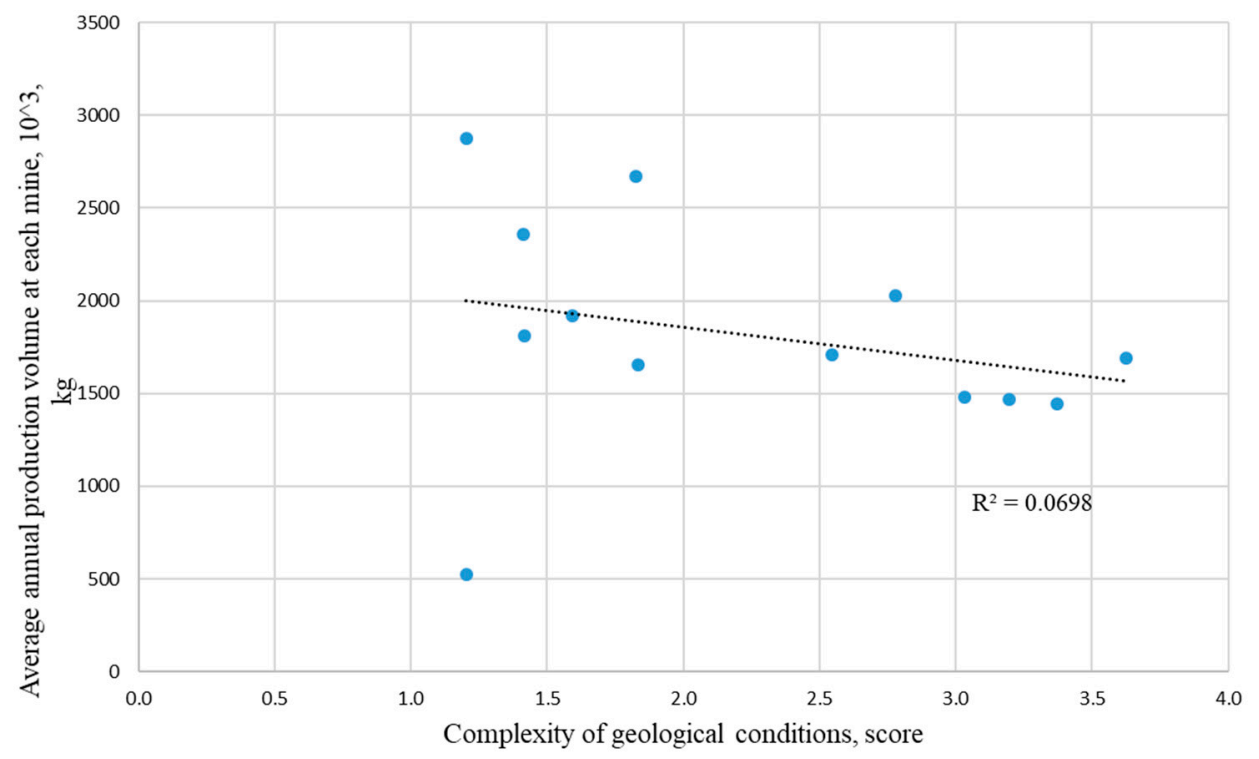

Figure 1. The figure illustrates the correlation between the average annual coal production volume and the score reflecting the complexity of geological conditions.

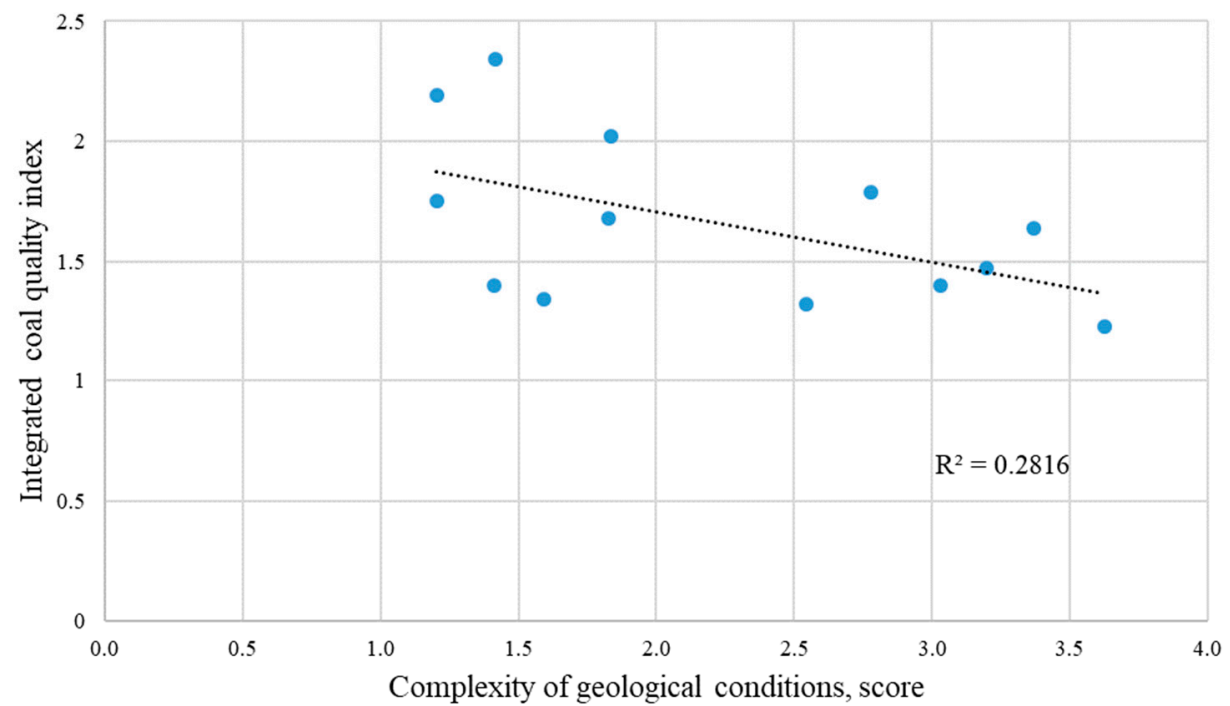

Figure 2. The figure illustrates the correlation between the integrated coal quality index and the score reflecting the complexity of geological conditions. 


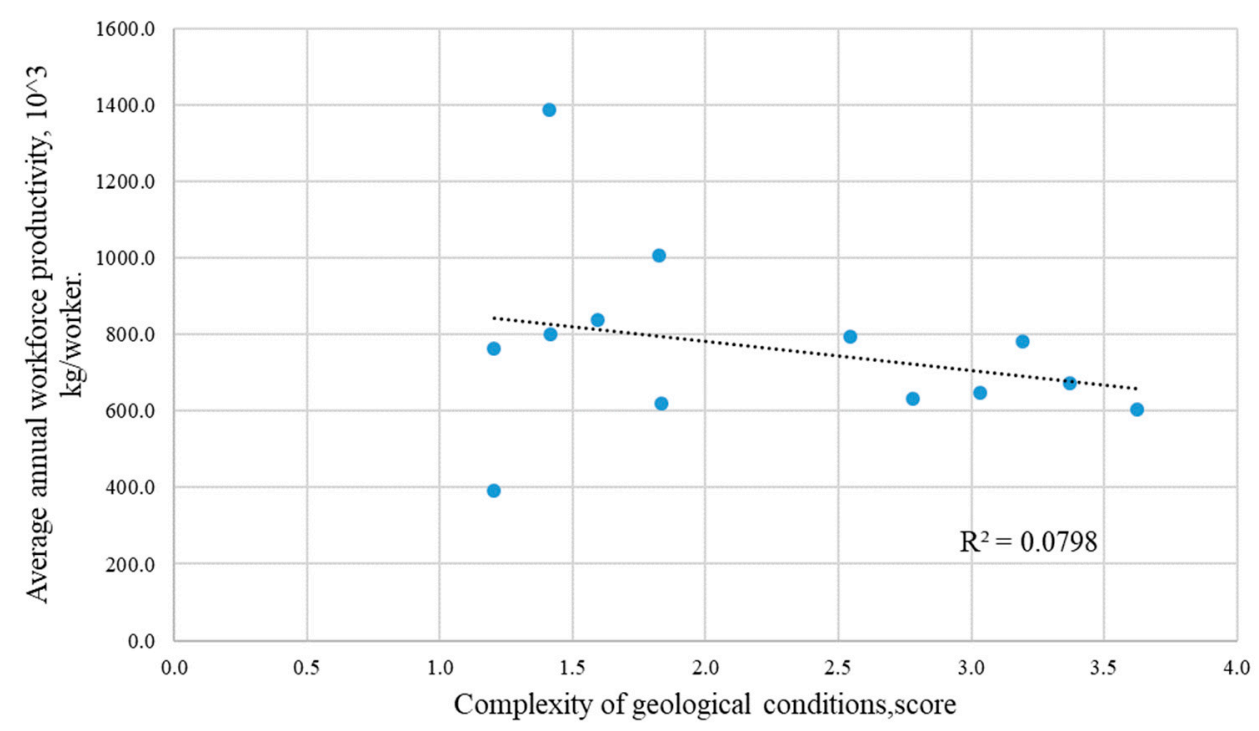

Figure 3. The figure illustrates the correlation between the average annual workforce productivity and the score reflecting the complexity of geological conditions.

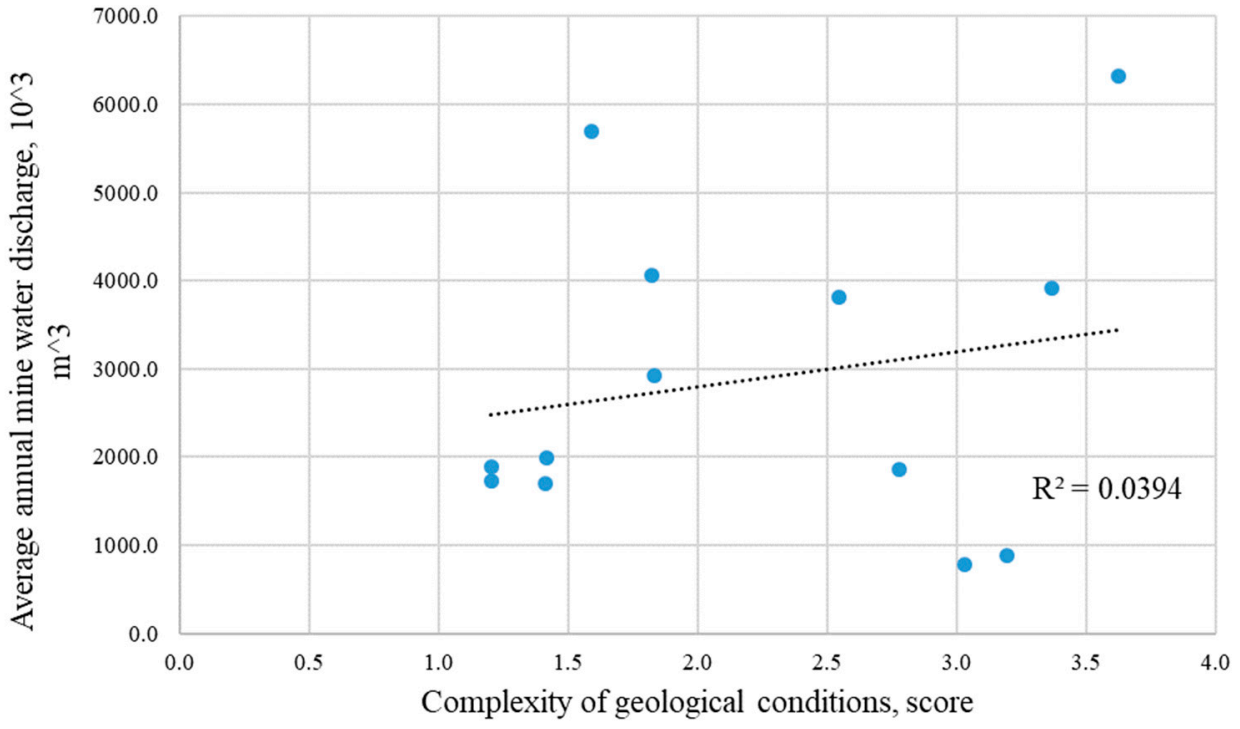

Figure 4. The figure illustrates the correlation between the average annual mine water discharge and the score reflecting the complexity of geological conditions.

The slope of the line indicates an inverse relationship between these indicators, and the value of the coefficient of determination shows that only $6.98 \%$ of the variation in production volumes is explained by the model under consideration.

There is an inverse relationship, which shows that geological conditions explain $28.16 \%$ of the variation in coal quality.

In this model, only $7.98 \%$ of the variation in the values of the average annual workforce productivity is explained by the influence of geological conditions.

In this case, the influence of geological conditions explains only $3.94 \%$ of the variation in the volumes of average annual mine water discharge.

Table 6 shows the results of assessing the strength of the relationships between production sustainability indicators and the indicators for assessing geological conditions based on pairwise correlation. To assess strength of relationship, Chaddock's scale (1925), which is a popular instrument, was used. 


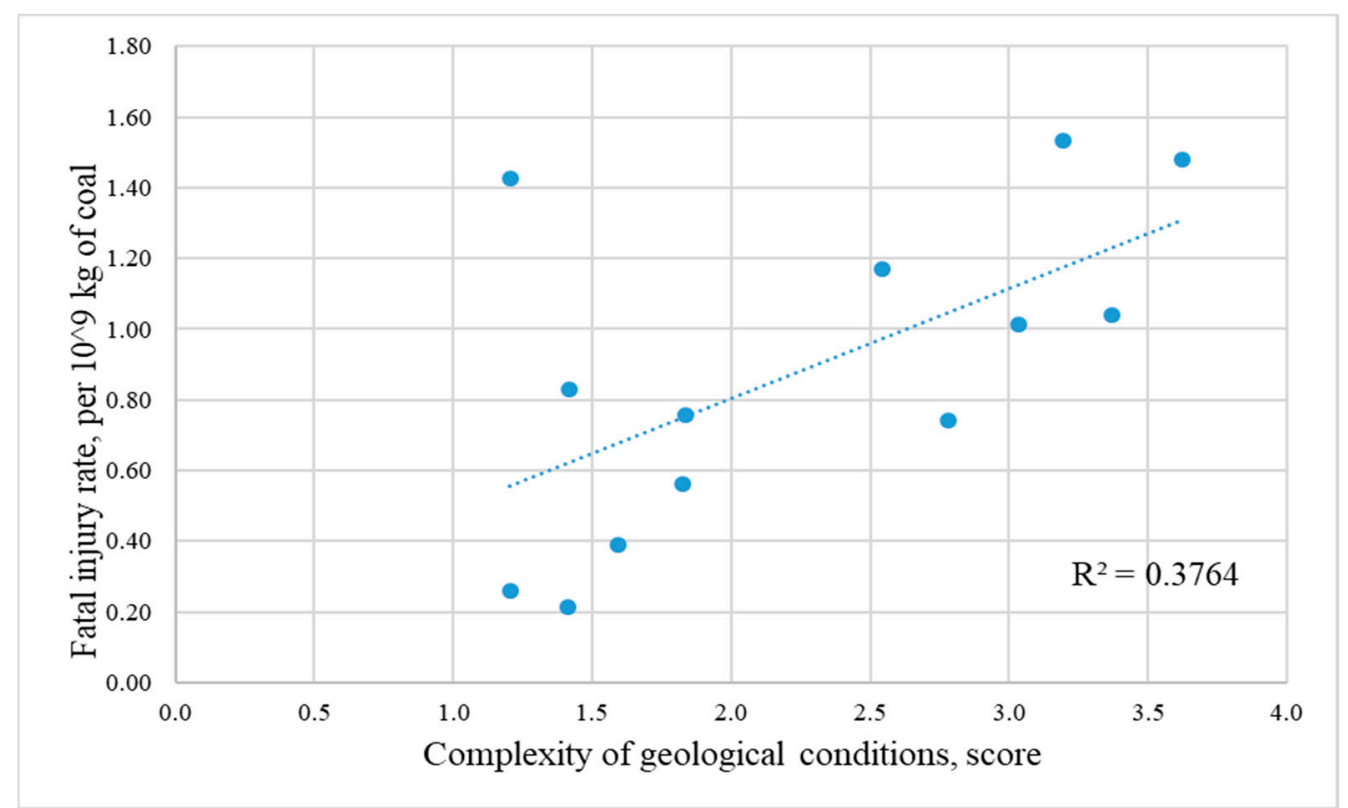

Figure 5. The figure shows the relationship between the number of fatal injuries at work and the score reflecting the complexity of geological conditions. The slope of the line shows that there is a direct relationship between these indicators, and $37.64 \%$ of the variation in the number of fatal injuries can be explained by the influence of geological conditions.

Table 6. Strength of the relationships between production sustainability indicators and the indicators for assessing geological conditions.

\begin{tabular}{lccc}
\hline & Production Sustainability Indicators & Correlation Coefficients, $\mathbf{r}$ & $\begin{array}{c}\text { Strength of Relationship on } \\
\text { Chaddock's Scale }\end{array}$ \\
\cline { 2 - 4 } & Production volume & 0.26 & Weak negative \\
\cline { 2 - 4 } $\begin{array}{l}\text { Factor: complexity of } \\
\text { geological conditions }\end{array}$ & Coal quality & 0.53 & Noticeable negative \\
\cline { 2 - 4 } & Workforce productivity & 0.28 & Weak negative \\
\cline { 2 - 4 } & Fatal injury rate & 0.61 & Noticeable positive \\
\cline { 2 - 4 } & Mine water discharge & 0.19 & Weak positive \\
\hline
\end{tabular}

Source: compiled by the authors based on [30].

According to Chaddock's scale, values of the correlation coefficient reflect the strength of the relationship as follows: 0.1 to 0.3 -weak; 0.3 to 0.5 -moderate; 0.5 to 0.7 -noticeable; 0.7 to 0.9 -high; 0.91 to 1 -very high. The complexity of geological conditions demonstrates a noticeable correlation only with the indicators reflecting the quality of coal and the fatal injury rate.

\section{Discussion}

Corporate sustainability assessment can be used to analyze the state and capabilities of a company with regard to achieving its goals and objectives and also identify problem areas and a combination of factors affecting the prospects for the company's development. As noted by S. Cleary and T. Malleret, sustainable companies demonstrate both low costs and a high level of innovations. They are flexible but not fragile. They keep things in order during times of instability and promote change when things are stable [31].

From the viewpoint of the systems approach, sustainability is a combination of dynamic components under control that demonstrate certain ratios at different stages of the company's life cycle and ensure the stability (sustainability) of its development [32].

Implementing strategies for the sustainable development of mining companies as complex production systems with long life cycles involves taking into account the influence of decisions on such spheres as the economy, society, and the environment by assessing 
costs, benefits, and risks while adhering to the principles of the feasibility and justifiability of production activities, improving the quality of labor, and improving the sustainability of ecosystems $[20,33]$. It is becoming of growing importance for coal mines to develop in a sustainable manner due to such an environmental challenge as global warming and its impacts, greater environmental awareness, and increasingly stringent and complex environmental regulations [19].

Scientific literature contains various points of view on sustainability. Different sources distinguish between economic, financial, production, technological, marketing, environmental, social, and other types of sustainability. For example, economic sustainability can be viewed as the ability of a company to achieve its goals $[34,35]$ or withstand the influence of external and internal factors [36]; it is also viewed as a condition for and addition to changeability [37].

For mining companies, the economic and environmental aspects of sustainability are associated with the demand for new mineral reserves, the depth of cover, the quality of mineral processing operations, utilizing the most productive equipment, minimizing the impact on nature, implementing environmental protection measures [37].

The need to take into account the social aspect is connected with the growing role of staff in production efficiency [38].

In [39], it is proposed to consider various types of sustainability as properties of individual subsystems of a production facility, which together form a system of the company's strategic sustainability that has hierarchical levels (operational, functional, and marketing ones), i.e., the operational, or production level, is fundamental to ensuring the strategic sustainability of the entire company.

Due to the specifics of the coal industry and the mining conditions in the Socialist Republic of Vietnam, it is necessary to focus the analysis specifically on the production sustainability of the coal-mining facilities that belong to the mining division of a stateowned corporation.

Scientific literature defines production sustainability as a production potential ensuring that the company's operations do not cause financial losses [40], or as the company's ability to efficiently use production resources while maintaining production stability and balancing its operations in changing external conditions [41]. In our opinion, it is impossible today to apply the market approach and methods for assessing production sustainability to the planned economy of Vietnam since coal production volumes are controlled by the state. A promising method proposed in [20] for assessing the sustainability of coal mines by taking into account the social, environmental, and economic factors is difficult to apply to Vietnamese coal mines due to the specifics concerning data availability and the country's statistical system.

Therefore, in this study, we mean by production sustainability the ability of coal companies to ensure a certain level of coal production and quality and to maintain production and environmental safety in order to have stable and positive production results in the long term.

Studies [42] note that business operations in the energy industry are complicated by the complexity and capital intensity of the resources and processes used. These circumstances require effective and efficient management that takes into account location specifics, geological conditions, and technological requirements associated with the development of coal deposits.

Geological conditions are considered to be the most important factor affecting the sustainability of coal production facilities. Vietnamese coal mines are characterized by harsh working conditions, including such factors as large depths of cover, complex geological structures of coal seams, geological faults, branching seams of various thicknesses, soft enclosing rocks, high water contents, and methane explosion hazards [43-45].

In this study, the assessment of the complexity of geological conditions is based on the scoring methodology proposed in [46] for classifying Russian coal mines. 
Difficult geological conditions create both obstacles for using modern technologies and additional risks [47]. Moreover, underground coal mining has a great impact on water resources. Surface and groundwater pollution as well as logging are among the biggest environmental problems associated with coal mining in Vietnam [48]. Minimizing negative impact on the environment and ensuring both occupational and product safety are prerequisites for production sustainability [49-51].

These circumstances influenced the choice of such indicators for the analysis as production volume, coal quality, workforce productivity, mine water discharge, and the fatal injury rate, as they give a comprehensive picture of a mine's production, social, economic, and environmental performance.

The choice of indicators influences how sustainability is reflected. The experience of Russian companies shows that an increase in profits does not always indicate positive socio-economic processes: even with a decrease in profits, there can be positive socioeconomic changes that improve the company's sustainability [52]. On the other hand, placing emphasis on social and environmental indicators only $[52,53]$ reduces the value of standard economic indicators and goes against the idea of business efficiency [54]. For analyzing the production sustainability of coal companies, the qualitative characteristics of coal are of great importance [55].

This study focuses on production sustainability indicators. Production sustainability is understood as the ability of coal companies to produce coal of a given quality in a given volume, maintain production, and ensure environmental safety in order to have stable and positive production results in the long term.

As each coal deposit is unique, it requires adjusting production processes. Geological conditions are a natural factor that affects the company's production results.

The quantitative assessment of geological conditions performed in the course of the study revealed that four mines (Nga Hai, Mong Duong, Khe Cham 3, and Mao Khe) have very difficult geological conditions, two mines (Vang Danh and Mao Khe) have easy conditions, three mines have difficult conditions, and four mines are characterized by moderately difficult conditions.

The hypothesis that geological conditions influence production sustainability indicators was generally confirmed. However, it cannot be said that the relationship is strong.

The low values of pairwise correlation coefficients demonstrate a weak dependence of production volumes $(\mathrm{r}=-0.26)$, workforce productivity $(\mathrm{r}=-0.28)$, and mine water discharge $(r=0.19)$ on geological conditions, which can be due to the influence of the adopted coal extraction and mine water treatment practices.

The noticeable positive relationship between the fatal injury rate and geological conditions $(r=0.61)$ can serve as a signal that it is necessary to develop safety measures to reduce the risk of accidents. The noticeable relationship between the quality of coal and geological conditions $(\mathrm{r}=-0.53)$ can also serve as a stimulus for developing measures to ensure the stability of production and maintain coal quality.

As a whole, the results of the study can be used to select targets for developing programs and individual measures within the coal division of Vinacomin.

The proposed methodology can also be tested using data from other coal companies.

Limitations of the study.

Coal mines operated by the Vinacomin corporation are part of the country's planned economy. They are under government control and have limited investment resources. Coal extracted in difficult geological conditions is used for domestic needs. Therefore, the key goal for coal mines is to ensure efficient and safe production. The proposed methodology was developed to factor in the specifics of coal production in Vietnam. This determined the choice of indicators and the methodological approach.

All the statistical calculations and correlation tests in the study were performed using MS Excel functions.

The questionnaire presented to the participants in the survey asked them to assign weights (from 1 to 10) to the criteria for assessing the complexity of geological conditions. 
When selecting the participants, such characteristics were taken into account as their specialty, position in the company, and work experience.

In this study, regression and correlation analysis was used only for the purpose of identifying whether there is a significant relationship between geological conditions and industrial sustainability indicators, and it is not implied that it must be used to identify causal relationships or make predictions.

As this is the first study of its kind, it is assumed that the results obtained can serve as a reference for monitoring coal mines and identifying mining facilities where measures can be implemented to improve their sustainability.

\section{Conclusions}

The strategic role of the fuel and energy sector in the industrial development of Vietnam and the fact that this sector produces coal, which is a non-renewable energy source, make it necessary to ensure the sustainability of both the coal industry as a whole and its core made of coal mines.

The proposed method was developed taking into account the specifics of both the coal industry in Vietnam and underground coal mining. The choice of indicators for the analysis was based on the principles of sustainable development declared by the country, which include stability, safety, and efficiency. At the production level, the influence of geological conditions on the social aspect of sustainability is most noticeably manifested in the form of accidents and injuries. However, this does not make it less important to take into account the environmental aspect when assessing the sustainability of coal companies.

The results of the study can be used to focus on specific mines and directions in the development of programs and measures aimed at maintaining the sustainability of Vinacomin's coal-mining facilities.

The proposed method can also be tested at other companies involved in underground coal mining.

Author Contributions: Conceptualization, M.N. and C.T.Q.; methodology, M.N.; software, C.T.Q.; validation, C.T.Q., M.N. and O.M.; formal analysis, O.M.; investigation, O.M.; resources, C.T.Q.; data curation, M.N.; writing—original draft preparation, C.T.Q.; writing—review and editing, M.N.; visualization, O.M.; supervision, M.N.; project administration, O.M. This research received no external funding. All authors have read and agreed to the published version of the manuscript.

Funding: This research received no external funding.

Institutional Review Board Statement: Not applicable.

Informed Consent Statement: Not applicable.

Data Availability Statement: In our work, we used the official data by the Vinacomin company, sites: https: / thuvienphapluat.vn/van-ban/tai-nguyen-moi-truong/Quyet-dinh-403-QD-TTg-dieu-chinhquy-hoach-phat-trien-nganh-than-Viet-Nam-2020-2030-306131; (accessed on 30 April 2021); http:/ / www.vinacomin.vn/gioi-thieu-chung/don-vi-thanh-vien-201507041650281216.html; (accessed on 30 April 2021); https: / thuvienphapluat.vn/van-ban/Tai-nguyen-Moi-truong/Quyet-dinh-25-200 7-QD-BTNMT-Quy-dinh-tham-do-phan-cap-tru-luong-tai-nguyen-than-62365.aspx (accessed on 30 April 2021). In addition, we received official permission from the company to use some data on mines: production volumes, coal quality, number of personnel, number of accidents at work.

Acknowledgments: The authors express their gratitude to the management at Vinacomin for the opportunity to use the company's reports and to the company's employees who provided consultations and took part in the survey.

Conflicts of Interest: The authors declare no conflict of interest the results. 


\section{References}

1. British Petroleum Statistical Review of World Energy; British Petroleum Corporate Communications Services: London, UK, 2020; p. 68.

2. Vietnam Wants to Abandon the Construction of New Coal-Fired Power Plants. Available online: https://tesiaes.ru/?p=15806 (accessed on 15 May 2021).

3. Paltasingh, T.; Satapathy, J. Unbridled coal extraction and concerns for livelihood: Evidences from Odisha, India. Miner. Econ. 2021, 34, 491-503. [CrossRef]

4. Batrancea, I.; Batrancea, L.; Nichita, A.; Gaban, L.; Masca, E.; Morar, I.D.; Fatacean, G.; Moscviciov, A. An econometric approach on production, costs and profit in Romanian coal mining enterprises. Econ. Res. Ekon. Istraž. 2019, 32, 1019-1036. [CrossRef]

5. Matemilola, S.; Fadey, O.; Sijuade, T. Paris Agreement. In Encyclopedia of Sustainable Management; Springer: Cham, Switzerland, 2020; pp. 1-5. [CrossRef]

6. Finkelman, R.B.; Wolfe, A.; Hendryx, M.S. The future environmental and health impacts of coal. Energy Geosci. 2021, 2, 99-112. [CrossRef]

7. Woch, M.W.; Radwańska, M.; Łopata, B. Relationships between waste physicochemical properties, microbial activity and vegetation at coal ash and sludge disposal sites. Sci. Total. Environ. 2018, 642, 264-275. [CrossRef] [PubMed]

8. Ianc, N.; Boantă, C.; Gherghe, I.; Tomescu, C. Environmental impact of methane released from coal mines. In Proceedings of the 9th International Symposium on Occupational Health and Safety (SESAM 2019), Petrosani, Romania, 3 October 2019. [CrossRef]

9. Nguyen, A.P. The role of the energy complex in ensuring the sustainable development of the economy of the Socialist Republic of Vietnam. Innov. Investig. 2020, 8, 84-86. Available online: https:/ / cyberleninka.ru/article/n/rol-energeticheskogo-kompleksa-vobespechenii-ustoychivogo-razvitiya-ekonomiki-sotsialisticheskoy-respubliki-vietnam (accessed on 15 May 2021).

10. Tran, T.H.Y.; Tran, T.T.T. Sustainability Analysis of Vietnam: Current Situation and Prospects. Econ. Yest. Tod. Tomorr. 2018, 8, 153-163. Available online: http:/ / publishing-vak.ru/file/archive-economy-2018-7/18-tran.pdf (accessed on 10 April 2021).

11. Nguyen, K.N. Development of the coal industry in Vietnam. Min. Mag. 2017, 1, 60-66.

12. Vinacomin. The Amendment "Planning the Development of the Coal Industry in Vietnam Until 2020, Taking into Account the Prospects Until 2030" Was Approved by Decision No. 403/2016/QD-TTg Dated March 14. 2016. Available online: https: / thuvienphapluat.vn/van-ban/Tai-nguyen-Moi-truong/Quyet-dinh-403-QD-TTg-dieu-chinh-quy-hoach-phat-triennganh-than-Viet-Nam-2020-2030-306131.aspx (accessed on 15 May 2021).

13. Nguyen, C.T. Current Situation, Supply-Demand, Coal Import: Challenges and Development Policy. NangluongVietNam, 2020. Available online: http:/ / nangluongvietnam.vn/news/vn/nhan-dinh-phan-bien-kien-nghi/thuc-trang-cung-cau-nhap-khauthan-thach-thuc-va-chinh-sach-phat-trien-ky-cuoi.html (accessed on 10 May 2021).

14. Coal Imports are Set to Rise to Record Levels in Vietnam. NVL, 2020. Available online: https://novostivl.ru/post/83415/ (accessed on 10 May 2021).

15. Tran, V.H. Justification of Solutions for the Rational Use of Mineral Resources and Environmental Protection in Vietnam. In State Scientific and Technical Program KS-08-28; Resource and environment: Hanoi, Vietnam, 2006; pp. 117-131.

16. Gendler, S.G.; Nguyen, T.H. Substantiation of rational ways to provide air for mining areas of operating coal mines in Vietnam while deepening mining operations. Zap. Gorn. Inst. 2018, 234, 652-657.

17. Zubov, V.P. Applied technologies and current problems of resource-saving in underground mining of stratified deposits. Gorn. Zhurnal 2018, 6, 77-83. [CrossRef]

18. Magomet, R.D.; Mironenkova, N.A. Methane problem of coal beds. Res. J. Pharm. Biol. Chem. Sci. 2016, 7, 2276-2284. Available online: http://www.rjpbcs.com/pdf/2016_7(3)/[275].pdf (accessed on 15 October 2021).

19. Trzeciak, M.; Jonek-Kowalska, I. Monitoring and Control in Program Management as Effectiveness Drivers in Polish Energy Sector. Diagnosis and Directions of Improvement. Energies 2021, 14, 4661. [CrossRef]

20. Burchart-Korol1, D.; Krawczyk1, P.; Czaplicka-Kolarz, K.; Turek, M.; Borkowski, W. Development of Sustainability Assessment Method of Coal Mines. J. Sustain. Mining 2014, 13, 5-11. [CrossRef]

21. Miletic, S.; Paunkovic, D.; Bogdanovic, D. Evaluation of sustainability indicators for decision-making in mining companies. Megatrend Rev. 2016, 13, 83-96. Available online: https://www.researchgate.net/publication/312660251 (accessed on 20 October 2021). [CrossRef]

22. Burduk, A. Stability Analysis of the Production System Using Simulation Models. In Process Simulation and Optimization in Sustainable Logistics and Manufacturing; Springer: Cham, Switzerland, 2014; pp. 69-83. [CrossRef]

23. Vasiliev, Y.N.; Kovalchuk, I.O. Analysis of the Competitiveness of Coal Products of Enterprises of the Russian Federation. In Proceedings of the Science and Innovation in Technical Universities, Saint Petersburg, Russia, 26-28 October 2016; pp. 144-145.

24. Provisions for the Provision and Distribution of Coal Resources Resolution No.: 25/2007/QD-BTNMT, on the Adoption of the Provisions for the Provision and Distribution of Coal Resources. Available online: https://thuvienphapluat.vn/van-ban/Tainguyen-Moi-truong/Quyet-dinh-25-2007-QD-BTNMT-Quy-dinh-tham-do-phan-cap-tru-luong-tai-nguyen-than-62365.aspx (accessed on 30 April 2021).

25. General Statistics Office. Employment Investigation Report. Vietnam, 2021; p. 219. Available online: https://www.gso.gov.vn/ wp-content/uploads/2021/08/sach_laodong_2020.pdf (accessed on 30 April 2021).

26. Research Data from Exploration Drilling of Coal Mines in Vietnam. Available online: https://openjicareport.jica.go.jp/pdf/1192 6201_03.pdf (accessed on 30 April 2021). 
27. Labor Accidents in the Coal Mining Sector Decrease. 2020. Available online: https:/ /laodong.vn/cong-doan/tai-nan-lao-dongtrong-linh-vuc-khai-thac-than-giam-823641.ldo (accessed on 11 May 2021).

28. Vinacomin. Green Development Atrategy of Coal Industry. 2021. Available online: http://camphaport.com.vn/chien-luoc-phattrien-xanh-cua-nganh-than-tt2068.html (accessed on 11 May 2021).

29. Minh, A. Production Associated with Environmental Protection, Sustainable Development. 2021. Available online: https:/ / moit.gov.vn/bao-ve-moi-truong/san-xuat-gan-voi-bao-ve-moi-truong-phat-trien-ben-vung.html (accessed on 20 April 2021)

30. Chaddock, R.E. Principles and Methods of Statistics; Houghton, Mifflin: Boston, MA, USA, 1925; 471p.

31. Cleary, W.; Malre, T. Global Risks. Business Success in Turbulent Times; Palgrave Macmillan: London, UK, 2011.

32. Barbier, E.B.; Burgess, J.C. The Sustainable Development Goals and the systems approach to sustainability October 2017. Econmics 2017, 11, 2017-2028.

33. Gong, D.C.; Kao, C.W.; Peters, B.A. Sustainability investments and production planning decisions based on environmental management. J. Clean. Prod. 2019, 225, 196-208. [CrossRef]

34. Suleimanova, Y.M. Economic Sustainability of the Enterprise: Concept and Features. Soc. Politics Econ. Law 2012, 3, 53-56. Available online: https://cyberleninka.ru/article/n/ekonomicheskaya-ustoychivost-predpriyatiya-ponyatie-i-osobennosti (accessed on 20 June 2021).

35. Nedosekin, A.O.; Reishahrit, E.I.; Kozlovsky, A.N. Strategic approach to assessing the economic sustainability of objects of the mineral resource complex in Russia. Zap. Gorn. Inst. 2019, 237, 354-360. Available online: https://cyberleninka.ru/article/n/ strategicheskiy-podhod-k-otsenke-ekonomicheskoy-ustoychivosti-obektov-mineralno-syrievogo-kompleksa-rossii (accessed on 20 June 2021).

36. Gorodilov, A.B. Ensuring the economic sustainability of the enterprise based on adaptive management. Actual Probl. Econ. Law 2011, 3, 91-97.

37. Lyaskovskaya, E.A. Economic sustainability of manufacturing enterprises: Concepts, factors, types. Bull. SUSU Ser. Econ. Manag. 2008, 5, 40-45.

38. Lehmann, A.; Zschieschang, E.; Traverso, M.; Finkbeiner, M.; Schebek, L. Social aspects for sustainability assessment of Technologies-Challenges for social life cycle assessment (SLCA). Int. J. Life Cycle Assess. 2013, 18, 1581-1592. [CrossRef]

39. Yashin, N.S.; Grigoryan, E.S. Methodology of strategic stability of the enterprise. Bull. Saratov State Soc. Econ. Univ. 2015, 1, 18-22. Available online: https:/ / cyberleninka.ru/article/n/metodologiya-strategicheskoy-ustoychivosti-predpriyatiya (accessed on 27 August 2021).

40. Kuzmicheva, V.V. Economic sustainability of an industrial enterprise: Essence, methods of assessment. Bull. Ivanovo State Univ. Ser. Econ. 2017, 1, 78-84.

41. Vasina, E.V. Production Stability as a Guarantee of Enterprise Stability. Actual Problems of Science and Technology: Collection of Works Based on the Materials of the IV International Competition of Scientific Research Works, Ufa; Scientific Publishing Center: Vestnik, Nauki, 2021; pp. 40-47.

42. Tilton, J.E. Cyclical and secular determinants of productivity in the copper, aluminum, iron ore, and coal industries. Miner Econ. 2014, 27, 1-19. [CrossRef]

43. Zubov, V.P.; Nikiforov, A.V. Features of development of superimposed coal seams in zones of disjunctive geological disturbances. Int. J. Appl. Eng. Res. 2017, 12, 765-768.

44. Zubov, V.P.; Nikiforov, A.V.; Kovalsky, E.R. Influence of geological faults on planning mining operations in contiguous seams. Ecol. Environ. Conserv. 2017, 2-3, 1176-1180.

45. Khau, L.V. Determination of parameters of the underground inclined coal seam mining in Quang Ninh basin under protected objects on the surface. J. Min. Inst. 2017, 226, 412-418. [CrossRef]

46. Andrianov, A.P.; Nabokov, A.I.; Vagapov, M.S.; Khomchenko, V.N. Typification of mining and geological factors affecting the conduct of underground mining. Vestn KuzGTU 2006, 45-48. Available online: https: / cyberleninka.ru/article/n/tipizatsiyagorno-geologicheskih-faktorov-vliyayuschih-na-vedenie-podzemnyh-gornyh-rabot (accessed on 27 August 2021).

47. Le, Q.P.; Zubov, V.P.; Phung, M.D. Improvement of the Loading Capacity of Narrow Coal Pillars and Control Roadway Deformation in the Longwall Mining System. A Case Study at Khe Cham Coal Mine (Vietnam). Inz. Miner. 2020, 1, 115-122. [CrossRef]

48. Le, B.D. Impact of Vietnamese Coal Mining Enterprises on the Hydrosphere. Bulletin of TulSU. Earth Sci. 2015, 1, 14-21. Available online: https:// cyberleninka.ru/article/n/vozdeystvie-ugledobyvayuschih-predpriyatiy-vietnama-na-gidrosferu (accessed on 30 April 2021).

49. Stock, T.; Seliger, G. Opportunities of sustainable manufacturing in industry 4.0. Procedia Cirp. 2016, 40, 536-541. [CrossRef]

50. Soloviov, V.B.; Magomet, R.D. The ways of safety improvement during the outburst-prone and gas-bearing coal seams development. J. Ind. Pollut. Control. 2017, 33, 1042-1047. Available online: https://www.icontrolpollution.com/articles/the-ways-ofsafety-improvement-during-the-outburstproneand-gasbearing-coal-seams-development-.pdf (accessed on 30 April 2021).

51. Nikulin, A.; Ikonnikov, D.; Dolzhikov, I. Increasing labour safety on coal mines. Int. J. Emerg. Trends Eng. Res. 2019, 7, 842-848. [CrossRef]

52. Labuschagne, C.; Brent, A.; Van Erch, R.P.G. Assessing the sustainability performances of industries. J. Clean. Prod. 2005, 13, 373-385. [CrossRef] 
53. Schoormann, T.; Behrens, D.; Kolek, E.; Knackstedt, R. Sustainability in business models-A literature-review-based designscience-oriented research agenda. In Proceedings of the European Conference on Information Systems (ECIS), Istanbul, Turkey, 12-15 June 2016; pp. 12-15. Available online: https:/ / aisel.aisnet.org/ecis2016_rp/134/ (accessed on 30 April 2021).

54. Kaplan, A.V.; Tereshina, M.A. Mining enterprises social-economic sustainable development assessment. Ugol'-Russ. Coal J. 2018, 8, 86-90. [CrossRef]

55. Afanasieva, N.V.; Rodionov, D.G.; Vasilev, Y.N. System of indicators of coal enterprise competitiveness assessment. Rev. Espac. 2018, 39, 10. Available online: https:/ /www.revistaespacios.com/a18v39n36/a18v39n36p10.pdf (accessed on 15 May 2021). 